\title{
Growth, thermal preference and critical thermal maximum for Totoaba macdonaldi: effect of acclimation temperature and inclusion of soybean meal in the diet
}

\author{
Eloy Eduardo Yen Ortega ${ }^{1}(\mathbb{D})$, Juan Gabriel Correa Reyes ${ }^{2}(\mathbb{D})$ \& Mónica Hernández Rodríguez ${ }^{1}$ (D) \\ ${ }^{1}$ Departamento de Acuicultura, Centro de Investigación Científica y de Educación Superior de Ensenada \\ (CICESE), B.C., México \\ ${ }^{2}$ Instituto de Investigaciones Oceanológicas, Universidad Autónoma de Baja California \\ B.C., México \\ Corresponding author: Mónica Hernández (mhernand@ cicese.mx)
}

\begin{abstract}
We studied the interaction effect between temperature 23 and $26^{\circ} \mathrm{C}$, and replacing fishmeal for soybean meal (SBM): 32, 43, and 56\% vs. a diet control on culture performance, thermal behavior, and critical thermal maximum (CTMax) of juvenile Totoaba macdonaldi. Fish were fed to apparent satiation three times daily for 61 days. The results showed that temperature had a significant effect $(P<0.05)$ on weight gain, percent weight gain, and specific growth rate, which were all higher in fish acclimated at $26^{\circ} \mathrm{C}$. The preferred temperature ranged between 26.4 and $27.7^{\circ} \mathrm{C}$, significantly influenced by acclimation temperature $(P<0.05)$ but not by diet. CTMax was influenced by acclimation temperature and SBM in the diet. Fish resistance decreased when the percent SBM in the diet was higher. Information on biological indicators for T. macdonaldi adds to the knowledge of a key Mexican species. Our study demonstrated that the use of SBM as an alternative to fishmeal in the diet and the interaction with temperature as a factor could affect this species' performance.
\end{abstract}

Keywords: Totoaba macdonaldi; acclimation temperature; soybean meal; growth; thermal biology

\section{INTRODUCTION}

Totoaba macdonaldi overfishing and habitat degradation of areas for breeding and spawning lead to depleting its natural stocks. This species is currently protected by a fishery moratorium issued by the Mexican government in 1975 (Flanagan \& Hendrickson 1976) and, since 1976, it has been listed in the Convention on International Trade in Endangered Species of Wild Fauna and Flora (CITES) Appendix I as threatened with extinction, and its international trade is prohibited (Findley 2010). Through hatcheries set up as Environmental Management Units for Wildlife Conservation (UMA, for its acronym in Spanish), totoaba is being bred in captivity for use repopulation, aquaculture research, and establishment of responsible commercial fisheries (www.iaes.gob.mx).
Totoaba (T. macdonaldi) is a species endemic to the Gulf of California (Flanagan \& Hendrickson 1976) that is considered to have aquaculture potential (RuedaLópez et al. 2011). Recent studies have evaluated its nutritional requirements (Badillo-Zapata et al. 2016, Barreto-Curiel et al. 2018, Fuentes-Quesada et al. 2018, Mata-Sotres et al. 2018). However, no studies have addressed the effect of the thermal conditions, particularly the interaction between temperature and diet, on its biological performance.

Temperature is considered the abiotic factor that most strongly influences aquatic organisms' biology and physiology (Beitinger \& Lutterschmidt 2011). Its effects on survival, growth (Morgan \& Metcalfe 2001), behavior (Pulgar et al. 2003), and physiological capacity (Pörtner 2001, Clark et al. 2013) are well documented. Simultaneously, the energy content of

Corresponding editor: Alvaro Bicudo 
food influences body temperature and metabolism (Guillaume et al. 2004).

Fish have developed the ability to respond to temperature variations by choosing thermal regions through behavioral thermoregulation (Bicego et al. 2007, Angilletta 2009). The temperature preferred by organisms is usually related to the thermal range in which the physiological, biochemical, and metabolic processes are more efficient (Beitinger \& Fitzpatrick 1979). Other responses of fish to temperature include thermal tolerance and resistance. It can be determined by 1) the static method, which evaluates the incipient lower and upper lethal temperatures (Lutterschmidt \& Hutchison 1997, Eme \& Bennet 2009), or 2) the dynamic method, which determines the critical thermal minimum (CTMin) and maximum (CTMax) (Cowles \& Bogert 1944, Bennett \& Beitinger 1997, Lutterschmidt \& Hutchinson 1997). Critical temperatures have been determined in fish and, since few specimens are required, they can be determined in endangered species (Gelbach et al. 1978, Lutterschmidt \& Hutchinson 1997). Also, critical temperatures can be recorded experimentally in a very short time (less than two hours) and reveal biotic or abiotic factors' influence on this response (Beitinger \& Lutterschmidt 2011). As critical temperatures are related to the natural environment, they have been used as indicators of stress and adaptation (Paladino et al. 1980).

Aquaculture feeds are commonly based on a fish meal (FM) due to its high protein content (Hardy 2008), the right balance of essential amino acids, high digestibility (Ayodele 2010), and high content of n-3 polyunsaturated fatty acids and other nutrients (NRC 2011a). Fishmeal is mainly obtained from pelagic fishes (Hardy \& Tacon 2002), whose natural populations are now declining due to overfishing. Thus, creating the need to identify alternative protein sources for aquaculture's future development (Naylor et al. 2009, Olsen \& Hasan 2012). Fishmeal is also expensive, making it unattractive for commercial aquaculture. Proteins from plant sources such as wheat, corn, pea, bean, peanut, sunflower, canola, and soy, among others (NRC 2011a), have been proposed as alternative sources since the amino acid composition of their proteins is similar to that of animal protein (Watanabe 2002). Unfortunately, these plant sources also contain other complex components that make them more difficult to assimilate than fishmeal (NRC 2011a). Therefore, the nutritional value of plant protein must be evaluated to elucidate the proportion that could be safely included in the diet (Glencross et al. 2007).

Soybean meal (SBM) is considered a high-quality protein source due to its amino acid content, making it a good fish culture option (Brown et al. 2008). SBM has been used to replace FM in fish and shrimp cultures with favorable results when percentages of up to $50 \%$ depending on the species- have been included (Glencross et al. 2004, Kader et al. 2012). To cultivate species with aquaculture potential, such as $T$. macdonaldi, it is important first to determine their nutritional requirements so that specific diets that promote their adequate growth under different temperature conditions can be formulated (López et al. 2006, Rueda-López et al. 2011, Perez-Velazquez et al. 2016).

Both temperature and diet separately affect the biological performance of organisms. However, some studies have shown that the interaction between temperature and diet quality can produce substantially different effects. Studies conducted to determine the preferred temperature of fish indicate that acclimation temperature (Reynolds \& Casterlin 1979) and diet quality (Pulgar et al. 2003, Killen 2014) significantly affect the temperature range selected. This interaction can influence food intake and, therefore, food efficiency, growth, and condition factor, among others (Eya et al. 2017).

In addition to the nutritional requirements of totoaba already reported (Badillo-Zapata et al. 2016, PerezVelazquez et al. 2016, Barreto-Curiel et al. 2018, Fuentes-Quesada et al. 2018, Mata-Sotres et al. 2018), further research is needed on how the diet quality changes when some fraction of fishmeal is replaced by plant protein, including the interaction with thermal conditions. This study aimed to evaluate the combined effect of temperature and diet quality (i.e. varying percentages of soybean meal) on the biological performance of juvenile $T$. macdonaldi evaluated in terms of growth, thermal growth coefficient, thermal preference, and critical thermal maximum.

\section{MATERIALS AND METHODS}

\section{Specimen collection and conditioning}

Totoaba macdonaldi juveniles hatched from ovulated eggs donated by the Centro Reproductor de Especies Marinas del Estado de Sonora (CREMES) at Bahía Kino, Sonora, Mexico. Eggs were incubated at $24^{\circ} \mathrm{C}$ and hatched in a $1 \mathrm{~m}^{3}$ tank in the Marine Fish Culture Laboratory of the Centro de Investigación Científica y de Educación Superior de Ensenada (CICESE). When the fish reached an average weight of $83 \pm 4.2 \mathrm{~g}$, they were transported at Instituto de Investigaciones Oceanológicas of the Universidad Autónoma de Baja California (IIO-UABC), and placed in two recirculation systems, each consisting of twelve 500-L plastic tanks at $24^{\circ} \mathrm{C}$, before their acclimation at 23 or $26^{\circ} \mathrm{C}$. 
Each experimental system consisted of a $1.2 \mathrm{~m}^{3}$ compensation tank, inside which a 7,500 W titanium heater was placed to keep the temperature constant, together with a 1/3 HP pump, a $6 \mathrm{ft}^{3}$ bead biofilter (PolyGeyser ${ }^{\circledR}$, Pneumatic Drop Bead Filter model PG7 International Filter Solutions, TX, USA), and a generic 30 GPM Protein Skimmer. Each system was assigned to one of the acclimation temperatures $\left(23\right.$ or $\left.26^{\circ} \mathrm{C}\right)$ previously selected based on the preferred value determined for 2-month-old juvenile T. macdonaldi by Talamás (2001). Twelve specimens were placed in each tank, and the culture was kept under controlled conditions of dissolved oxygen $\left(7.4 \pm 0.8 \mathrm{mg} \mathrm{L}^{-1}\right)$, salinity $\left(32 \pm 1 \mathrm{~g} \mathrm{~L}^{-1}\right), \mathrm{pH}(8 \pm 0.1)$, and natural photoperiod (autumn season). Temperature, dissolved oxygen, and salinity were recorded daily with a multiparameter (YSI model 85-10); pH, ammonium, nitrites, nitrates, and alkalinity were measured using a commercial test kit (API ${ }^{\circledR}$ Test Kit, ApiFishcare ${ }^{\circledR}$ ) at three-day intervals.

\section{Experimental diets}

Four isoproteic $(50 \%)$ and isolipid (10\%) diets were formulated according to the nutritional requirements of T. macdonaldi as determined by Rueda-López et al. (2011) (Table 1). The diets were prepared in the Laboratorio de Investigación y Desarrollo para la Acuacultura (LINDEAACUA) at IIO-UABC. In three of the diets, the main protein source, fish meal (FM), was partially replaced with varying proportions of soybean meal (SBM), as follows: diet 1 (D1): 68\%FM$32 \%$ SBM, diet 2 (D2): 57\%FM-43\%SBM, and diet 3 (D3): 44\%FM-56\%SBM. Lipid concentration in the three diets was adjusted by adding fish oil in proportion to FM replacement. The fourth feed was the control diet (CD): $100 \%$ FM, which lacked SBM and had FM as the main protein source.

\section{Proximate analysis}

The four diets (control and diets with partial replacement of fishmeal with soybean meal) were determined using standard procedures (AOAC 1990); the results were expressed on a dry-matter basis. Ash content was determined by incineration of organic matter at $500^{\circ} \mathrm{C}$ for $24 \mathrm{~h}$ in a muffle (Lindberg/Blue model BF51842PBFMC-1). Moisture content was calculated from $1.0 \mathrm{~g}$ samples dried in the muffle to constant weight at $70^{\circ} \mathrm{C}$ for $24 \mathrm{~h}$. Total nitrogen content $(\% \mathrm{~N})$ was determined using the micro-Kjeldahl method, and the percentage of crude protein $(\mathrm{CP})$ was calculated as $\% \mathrm{~N} \times 6.25$. Total lipid content was determined after Soxhlet extraction with petroleum ether; the dissolved fat was then dried and evaluated by gravimetry. The nitrogen-free extract (NFE) was calculated using the equations proposed by OlveraNovoa et al. (1994).

\section{Culture conditions}

All the procedures performed in this study for the experimental culture of $T$. macdonaldi followed the NRC (2011b) guidelines for ethical and responsible research.

Fish with an average weight of $83 \pm 4.2 \mathrm{~g}$ were acclimated at either 23 or $26^{\circ} \mathrm{C}$. During the first week, the fish were fed a commercial diet (Europe-Skretting $2.0 \mathrm{~mm}, 50 \%$ protein, $8 \%$ lipid) at a daily feeding rate of $3 \%$ of the average body weight, divided into three servings a day. During the second week, the commercial diet was gradually replaced $(20 \%$ per day to reach 100\%) with the experimental diets (CD, D1, D2, and D3).

Juvenile fish reached an average weight of $100.6 \pm$ $0.21 \mathrm{~g}$ by the end of the two-week conditioning period. At that time, the experimental temperature-diet trials began. From day 1 to day 61 of culture, fish were fed the experimental diets to apparent satiation three times daily $(8: 00,12: 00$ and 16:00 h). Any food not consumed was removed after $30 \mathrm{~min}$ of remaining in the water column; feces were removed daily before the first feeding and half an hour after the last feeding of the day.

All fish were measured (total length, $\mathrm{cm}$ ) and weighed $(\mathrm{g})$ at the beginning of the experimental trial and then every month for two months. The biological performance of fish was evaluated in terms of survival (\%), percent weight gain (WG), specific growth rate (SGR), feed conversion ratio (FCR), and thermal growth coefficient (TGC):

$$
\text { Survival }=\frac{\text { final number of fish }}{\text { initial number of fish }} \times 100
$$

WG $(\%)=[($ final average wet weight - initial average wet weight $) \times 100 /$ initial average wet weight]

$$
\begin{gathered}
\operatorname{SGR}\left(\mathrm{d}^{-1}\right)=\frac{[\ln \text { final weight }(\mathrm{g})-\ln \text { initial weight }(\mathrm{g})]}{\text { days of culture }} \times 100 \\
\mathrm{FCR}=\frac{\text { total feed consumed }(\mathrm{g})}{\text { wet weight gained }(\mathrm{g})} \\
\mathrm{TGC}=\frac{\left(\text { final weight }(\mathrm{g})^{1 / 3}-\text { initial weight }(\mathrm{g})^{1 / 3}\right)}{\left.\mathrm{T}\left({ }^{\circ} \mathrm{C}\right) \times \text { days }\right)} \times 1000
\end{gathered}
$$

\section{Preferred temperature}

The system designed by Bückle et al. (2003) was used for the study of thermoregulatory behavior. This system consists of a $26 \mathrm{~cm}$ high, $31 \mathrm{~cm}$ wide and $365 \mathrm{~cm}$ long 
Table 1. Ingredients in diets formulated $\left(\mathrm{g} \mathrm{kg}^{-1}\right)$ for cultivating juvenile Totoaba macdonaldi at two acclimation temperatures. CD: control diet, D1: diet 1, D2: diet 2, D3: diet 3, FM: fish meal, SBM: soybean meal. Rovimix ${ }^{\circledR}$; vitamin and mineral mix $\left(\mathrm{g} \mathrm{kg}^{-1}\right)$ : $\rho$-aminobenzoic acid 1.45; biotin 0.02; myo-inositol 14.5; nicotinic acid 2.9; Capantothenate 1.0; pyridoxine- $\mathrm{HCl} 0.17$; riboflavin 0.73 ; thiamine- $\mathrm{HCl} 0.22$; menadione 0.17 ; $\alpha$-tocopherol 1.45 ; cyanocobalamin 0.0003 ; calciferol 0.03; L-ascorbyl-2- phosphate-Mg 0.25; folic acid 0.05; choline chloride 29.65; retinol 0.015; $\mathrm{NaCl} 1.838$; $\mathrm{MgSO}_{4} \cdot 7 \mathrm{H}_{2} \mathrm{O}$ 6.85; $\mathrm{NaH}_{2} \mathrm{PO}_{4} \cdot 2 \mathrm{H}_{2} \mathrm{O}$ 4.36; $\mathrm{KH}_{2} \mathrm{PO}_{4}$ 11.99; $\mathrm{Ca}\left(\mathrm{H}_{2} \mathrm{PO}_{4}\right)_{2} \cdot 2 \mathrm{H}_{2} \mathrm{O}$ 6.79; Fe-citrate 1.48; Ca-lactate 16.35; $\mathrm{AlCl}_{3} \cdot 6 \mathrm{H}_{2} \mathrm{O} 0.009 ; \mathrm{ZnSO}_{4} \cdot 7 \mathrm{H}_{2} \mathrm{O} 0.17 ; \mathrm{CuCl}_{2} 0.0005 ; \mathrm{MnSO}_{4} \cdot 4 \mathrm{H}_{2} \mathrm{O}$ 0.04; KI 0.008; $\mathrm{CoCl}_{2} 0.05$ and Stay-C (vitamin C) donated by DSM, Nutritional Products Guadalajara, Mexico.

\begin{tabular}{|c|c|c|c|c|}
\hline Ingredient & $\begin{array}{c}\mathrm{CD} \\
(100 \% \mathrm{FM})\end{array}$ & $\begin{array}{c}\mathrm{D} 1 \\
(68 \% \mathrm{FM}-32 \% \mathrm{SBM})\end{array}$ & $\begin{array}{c}\mathrm{D} 2 \\
(57 \% \mathrm{FM}-43 \% \mathrm{SBM})\end{array}$ & $\begin{array}{c}\text { D3 } \\
(44 \% \mathrm{FM}-56 \% \mathrm{SBM})\end{array}$ \\
\hline Fish meal & 620.5 & 424.9 & 355.0 & 272.1 \\
\hline Soy concentrate & 0.0 & 100.0 & 100.0 & 100.0 \\
\hline Soybean meal & 0.0 & 128.8 & 255 & 405.3 \\
\hline Cornmeal & 171.5 & 117.9 & 53.6 & 0.0 \\
\hline Wheat flour & 44.9 & 45.0 & 45.0 & 22.6 \\
\hline Lysine & 0.0 & 1.2 & 1.3 & 1.3 \\
\hline Methionine & 0.0 & 1.5 & 1.9 & 2.4 \\
\hline Fish oil & 35.4 & 53.0 & 60.5 & 68.6 \\
\hline Taurine & 10.0 & 10.0 & 10.0 & 10.0 \\
\hline Gelatin & 50.0 & 50.0 & 50.0 & 50.0 \\
\hline Native starch & 40.0 & 40.0 & 40.0 & 40.0 \\
\hline Rovimix $^{\circledR}$ & 25.0 & 25.0 & 25.0 & 25 \\
\hline Stay C & 0.5 & 0.5 & 0.5 & 0.5 \\
\hline Sodium benzoate & 2.0 & 2.0 & 2.0 & 2.0 \\
\hline BHT & 0.1 & 0.1 & 0.1 & 0.1 \\
\hline Choline chloride & 0.1 & 0.1 & 0.1 & 0.1 \\
\hline Total & 1000 & 1000 & 1000 & 1000 \\
\hline \multicolumn{5}{|c|}{ Proximate composition $\mathrm{g} \mathrm{kg}^{-1}$ (analyzed) } \\
\hline Crude protein & 484.27 & 486.76 & 490.23 & 487.82 \\
\hline Total lipids $\left(\mathrm{g} \mathrm{kg}^{-1}\right)$ & 91.27 & 93.54 & 93.37 & 93.76 \\
\hline $\begin{array}{l}\text { Nitrogen-free } \\
\text { extract }\end{array}$ & 215.21 & 234.82 & 237.56 & 255.04 \\
\hline Ash $\left(\mathrm{g} \mathrm{kg}^{-1}\right)$ & 137.24 & 118.82 & 105.28 & 96.46 \\
\hline Energy $\left(\mathrm{KJ} \mathrm{g}^{-1}\right)$ & 15.83 & 15.88 & 15.76 & 15.54 \\
\hline $\begin{array}{l}\mathrm{E}: \mathrm{P} \text { ratio } \\
\left(\mathrm{mg} \text { protein } \mathrm{KJ}^{-1}\right)\end{array}$ & 30.60 & 30.65 & 31.10 & 31.39 \\
\hline
\end{tabular}

Plexiglas channel with a total capacity of 220 L, subdivided into 15 virtual chambers, each measuring $20.33 \mathrm{~cm}$ long. A temperature sensor connected to a multichannel thermograph (Stanford Research Systems, model SR630) was placed at the center of each virtual chamber; temperature data were sent to a printer (Panasonic KX-P3696 Multi-mode) every $10 \mathrm{~min}$. Water temperature at one end of the channel was raised using two 1,000 W titanium heaters; the water at the opposite end was cooled off using a heat exchanger (Neslab Merlin M150), creating a $20-33^{\circ} \mathrm{C}$ thermal gradient along the channel.

The thermal preference study was carried out using four fish from each experimental unit; each time, two fish were placed in the gradient chamber corresponding to their acclimation temperature $\left(23\right.$ or $\left.26^{\circ} \mathrm{C}\right)$. After a
30 min transition period, the fish's location along the channel and the chambers' temperature were recorded every $10 \mathrm{~min}$ for $2.5 \mathrm{~h}$. All the experiments were run in triplicate, separately for each diet by temperature combination. Water was continuously injected $(80 \mathrm{~mL}$ $\mathrm{min}^{-1}$ ) into the system at one end of the channel to replace approximately $50 \%$ of the volume in $24 \mathrm{~h}$ to prevent the accumulation of metabolites.

\section{Critical thermal maximum (CTMax)}

Four fish from each experimental unit were used for the CTMax study. A single fish was placed in a $150 \mathrm{~L}$ plastic tank containing $60 \mathrm{~L}$ of water. Water temperature was increased at a constant rate of $1^{\circ} \mathrm{C} \mathrm{min}{ }^{-1}$ (Jobling 1981, Lutterschmidt \& Hutchison 1997) using three $1000 \mathrm{~W}$ heaters attached to a diffusing stone to 
maintain a continuous air supply, achieve a homogeneous temperature, and avoid stratification in the water column.

As the water temperature was raised, the thermal value was recorded when the fish exhibited the loss of balance response (Lutterschmidt \& Hutchison 1997, Beitinger et al. 2000). At the end of the test, the fish were killed under ethical and responsible research (NRC 2011b) guidelines.

Fish were not fed $24 \mathrm{~h}$ before the preferred temperature and CTMax experiments to avoid interference by post-digestion processes.

\section{Statistical analyses}

Percent values were arcsine transformed before statistical analyses. All the data were tested for normality (Kolmogorov-Smirnov, Lilliefors, and Shapiro-Wilk tests) and homogeneity of variance (Levene test). Twoway ANOVAs were carried out to evaluate the effects of acclimation temperature, experimental diets, and the interaction between the two factors. Dunnett's post-hoc test was used to compare each of the fishmealreplacement treatments with the control diet. Fisher's least significant difference test was used to test for differences between the different treatments means. All the analyses were performed at a 0.05 significance level using the software Statistica $10^{\mathrm{TM}}$ (StatSoft, Inc. USA).

\section{RESULTS}

\section{Biological performance: survival, specific growth rate, and thermal growth coefficient}

A two-way ANOVA showed that neither the main factors (i.e. acclimation temperature and diet) nor their interaction significantly affected survival. A 100\% survival was recorded in most treatments, except for the $23^{\circ} \mathrm{C}$ acclimation temperature $\times \mathrm{D} 1$ treatment, in which a $97 \%$ survival was recorded (Table 2).

Two-way ANOVAs showed that only acclimation temperature significantly affected final average weight, percentage weight gain, and the specific growth rate. Neither diet nor the interaction between the two experimental factors had any significant effect on these variables. The highest average weight was attained by fish acclimated at $26^{\circ} \mathrm{C}$ fed $\mathrm{D} 2(264.17 \pm 7.9 \mathrm{~g})$; this was significantly higher than the average weight attained by fish acclimated at $23^{\circ} \mathrm{C}$ and fed D1 (230.3 $\pm 14 \mathrm{~g} ; P=0.016), \mathrm{D} 2(223.0 \pm 9.0 \mathrm{~g} ; P=0.004)$, or D3 $(235.0 \pm 25 \mathrm{~g} ; P=0.34)$. There were no significant differences between the SBM diets and the control diet (Table 2).
The largest average percent weight gain $(155.9 \pm$ $30 \%$ ) was attained by fish acclimated at $26^{\circ} \mathrm{C}$ fed D3 (44\%FM-56\%SBM); this was significantly larger than the weight gained by fish acclimated at $23^{\circ} \mathrm{C}$ fed D1 $(120.7 \pm 15 ; P=0.024), \mathrm{D} 2(107.2 \pm 12 ; P=0.003)$ or D3 $(121.6 \pm 23 ; P=0.27)$. There were no significant differences in percent WG between the SBM diets and the $\mathrm{CD}\left(139.6 \pm 9 \%\right.$ at $23^{\circ} \mathrm{C}$ and $137.8 \pm 16 \%$ at $\left.26^{\circ} \mathrm{C}\right)$ (Table 2).

The highest SGR $\left(1.53 \pm 0.05 \mathrm{~d}^{-1}\right)$ was observed in fish acclimated at $26^{\circ} \mathrm{C}$ and fed $\mathrm{D} 2$; this was significantly higher than the SGR recorded in fish acclimated at $23^{\circ} \mathrm{C}$ and fed D1 $(1.31 \pm 0.1 ; P=0.021)$, D2 $(1.25 \pm 0.06 ; P=0.005)$ or D3 $(1.33 \pm 0.17 ; P=$ $0.035)$. There were no significant differences in SGR between the SBM diets and the CD.

A two-way ANOVA showed that diet had a significant effect $(P=0.02)$ on the feed conversion ratio (FCR), but neither acclimation temperature $(P=0.32)$ nor the interaction between the two experimental factors $(P=0.34)$ had any significant effect. The FCR of fish acclimated at $23^{\circ} \mathrm{C}$ and fed $\mathrm{D} 3$ was significantly higher $(P=0.023)$ than that of fish fed $\mathrm{CD}$ at $23^{\circ} \mathrm{C}$. Among the SBM treatments, the lowest average FCR $(1.03 \pm 0.02)$ was recorded in fish acclimated at $26^{\circ} \mathrm{C}$ and fed D2 (57\%FM-43\%SBM), and this was significantly lower $(P=0.031)$ than the highest value $\left(\mathrm{D} 3,23^{\circ} \mathrm{C}\right)$. Neither the main experimental factors (i.e. acclimation temperature and diet) nor their interaction had any significant effect on the thermal growth coefficient (TGC) (Table 2).

\section{Preferred temperature}

A two-way ANOVA showed that only acclimation temperature had a significant effect $(P=0.001)$ on the preferred temperature; neither diet $(P=0.99)$ nor the interaction $(P=0.08)$ between the two experimental factors had any significant effect on this variable.

The highest preferred temperature $\left(27.7^{\circ} \mathrm{C}\right)$ selected by fish acclimated at $23^{\circ} \mathrm{C}$ was significantly higher than the lowest temperature $\left(26.4^{\circ} \mathrm{C}\right)$ preferred by totoabas acclimated at $26^{\circ} \mathrm{C}$ (Fig. 1).

\section{Critical thermal maximum (CTMax)}

The CTMax was defined as the temperature at which $100 \%$ of the fish evaluated showed the loss of equilibrium response. A two-way ANOVA showed that both temperature $(P=0.001)$ and $\operatorname{diet}(P=0.047)$ had a significant effect on CTMax, but there was no significant interaction effect $(P=0.087)$. Fish resistance decreased as the percentage of SBM in the diet increased (Fig. 2). 


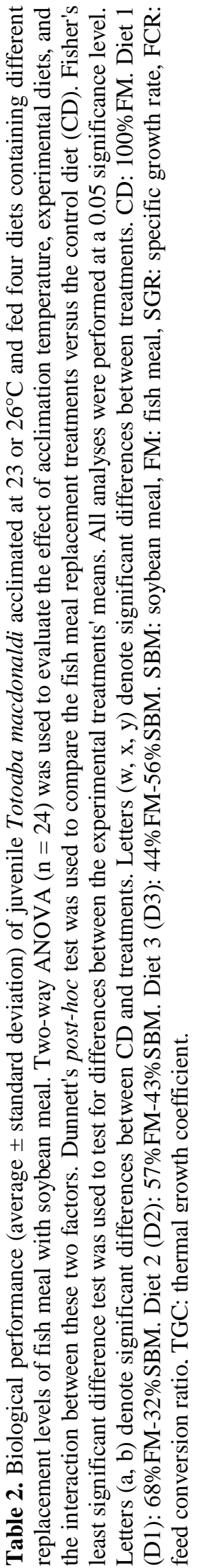

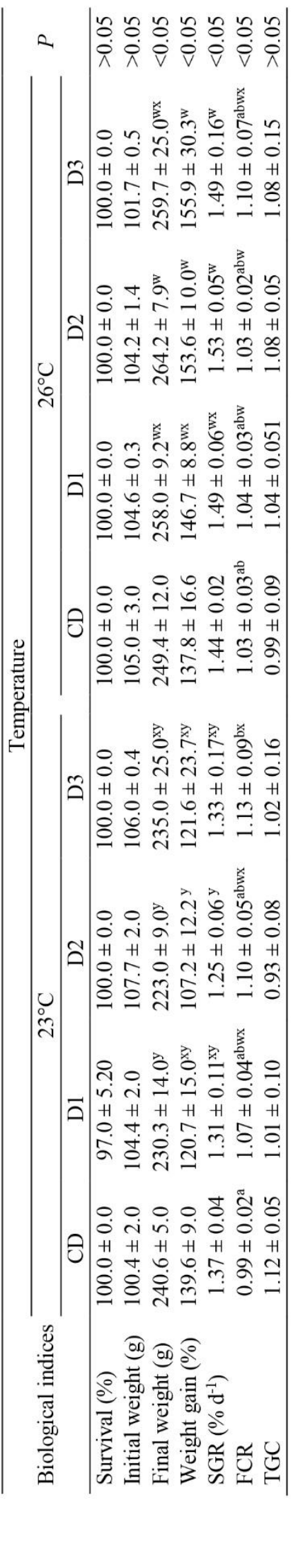

There were significant differences in the CTMax of fish fed CD vs. fish fed SBM diets. The CTMax $\left(37.3^{\circ} \mathrm{C}\right)$ of fish acclimated at $23^{\circ} \mathrm{C}$ and fed $\mathrm{CD}$ was significantly lower $(P<0.0001)$ than the CTMax $\left(38.2^{\circ} \mathrm{C}\right)$ of fish fed the same diet but acclimated at $26^{\circ} \mathrm{C}$. The CTMax observed in this treatment $(\mathrm{CD}$, $26^{\circ} \mathrm{C}$ ) was also significantly different versus most other treatments, except for fish fed D1 and acclimated at $26^{\circ} \mathrm{C}\left(37.8^{\circ} \mathrm{C} ; P=0.12\right)$.

The highest average CTMax $\left(37.8^{\circ} \mathrm{C}\right)$ was recorded in fish acclimated at $26^{\circ} \mathrm{C}$ and fed D1 (68\%FM$32 \% \mathrm{SBM}$ ); this was significantly higher relative to fish acclimated at $23^{\circ} \mathrm{C}$ and fed $\mathrm{D} 2\left(37.3^{\circ} \mathrm{C} ; P=0.01\right)$ or D3 $\left(37.2^{\circ} \mathrm{C} ; P=0.003\right)$. The lowest CTMax was observed in totoabas acclimated at $23^{\circ} \mathrm{C}$ and fed D3; this was significantly lower relative to fish acclimated at $26^{\circ} \mathrm{C}$ and fed D1 $(P=0.003), \mathrm{D} 2\left(37.6^{\circ} \mathrm{C} ; P=0.02\right)$, or $\mathrm{D} 3\left(37.7^{\circ} \mathrm{C} ; P=0.014\right)$ (Fig. 2$)$.

\section{DISCUSSION}

\section{Biological performance}

This study evaluated the interaction effect of temperature and the quality of diets formulated by replacing FM with SBM in varying proportions $(32,43$, and 56\%) on the performance of Totoaba macdonaldi. Survival after 61 days of cultivation was unaffected by either acclimation temperature or percent SBM in the diet. Fish acclimated at 23 and $26^{\circ} \mathrm{C}$, recorded $100 \%$ survival; a $97 \%$ survival was recorded in the $23^{\circ} \mathrm{C} \times \mathrm{D} 1$ treatment because one fish jumped out of the tank. Similar high survival rates $(>97 \%)$ have been reported for T. macdonaldi acclimated at $23^{\circ} \mathrm{C}$ and fed diets in which FM was replaced either with 15 to $100 \%$ soy protein concentrate (SPC), supplemented or not with $1 \%$ taurine (Bañuelos-Vargas et al. 2014, López et al. 2015, Trejo-Escamilla et al. 2016), or with 24, 44, or $64 \%$ SBM with $1 \%$ taurine (Fuentes-Quesada et al. 2018). High survival rates have been reported for other species in the family Sciaenidae such as Nibea miichthioides (Wang et al. 2006), Argyrosomus regius (Velazco-Vargas et al. 2013), Sciaenops ocellatus, and Cynoscion parvipinnis (Minjarez-Osorio et al. 2016) when fed diets containing varying percentages of SBM (15 to $100 \%$ ) or SCP (25 to $75 \%$ ). However, those authors did not evaluate the interaction effect between temperature and diet quality. Our study highlights the importance of this interaction to know the performance of $T$. macdonaldi because, in culture conditions, the thermal variation has a marked influence on fishes' physiology.

Average weight, specific growth rate, and percentage weight gain were all influenced only by acclima- 


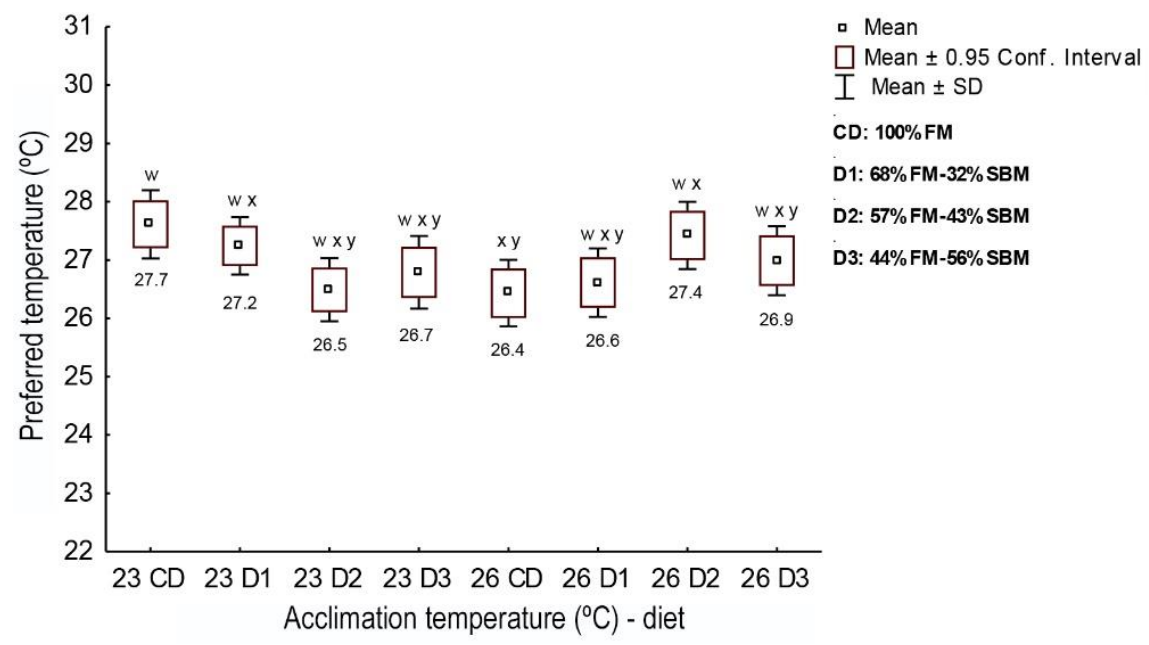

Figure 1. Preferred temperature (average \pm standard deviation, SD) of juvenile Totoaba macdonaldi acclimated at 23 and $26^{\circ} \mathrm{C}$ and fed four diets containing different levels of replacement of fish meal (FM) with soybean meal (SBM). Two-way ANOVA ( $n=24$ per treatment) were used to evaluate the effect of acclimation temperature, experimental diets, and the interaction between these two factors. Dunnett's post hoc test was used to compare the fish meal replacement treatments vs. control diet (CD). Fisher's least significant difference test was used to test for differences between the experimental treatments' means. All analyses were performed at a 0.05 significance level. Letters (w, x, y) denote significant differences between treatments.

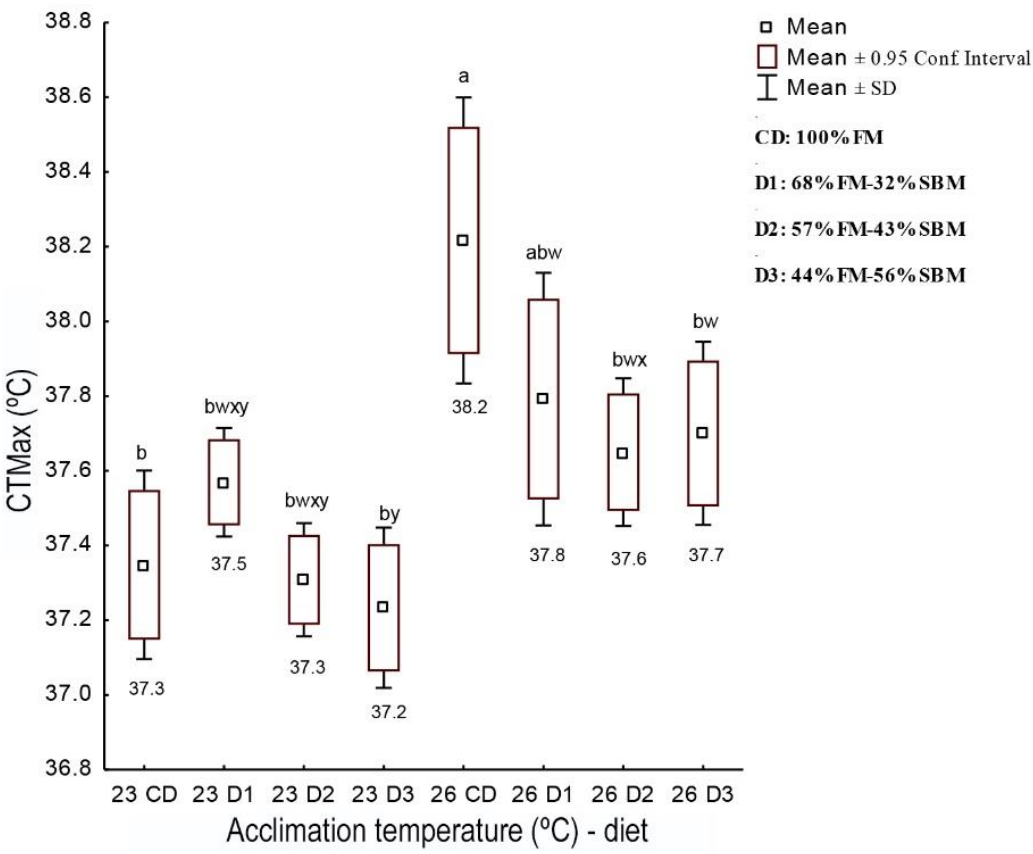

Figure 2. Critical thermal maximum (average \pm standard deviation, SD) of juvenile Totoaba macdonaldi acclimated at 23 and $26^{\circ} \mathrm{C}$ and fed four diets containing different levels of replacement of fish meal (FM) with soybean meal (SBM). Twoway ANOVA $(n=96)$ were used to evaluate the effect of acclimation temperature, experimental diets, and the interaction between these two factors. Dunnett's post-hoc test was used to compare the fish meal replacement treatments $v s$. control $\operatorname{diet}(\mathrm{CD})$. Fisher's least significant difference test was used to test for differences between the experimental treatments' means. All analyses were performed at a 0.05 significance level. Letters $(a, b)$ denote significant differences between CD and treatments. Letters (w, x, y) denote significant differences between treatments. CTMax $\left({ }^{\circ} \mathrm{C}\right)$ : critical thermal maximum.

tion temperature. The highest values for these indices were observed in fish acclimated at $26^{\circ} \mathrm{C}$. The lowest weights were recorded in fish acclimated at $23^{\circ} \mathrm{C}$ and fed diets containing varying percentages $(32,43$, and 
$56 \%$ ) of soybean meal. In our study, the higher values were obtained in the percent weight gain (WG) and SGR, compared to those reported for this same species by Espinosa-Chaurand et al. (2015), Perez-Velazquez et al. (2016), and González-Félix et al. (2018) (Table 3).

The differences in SGR values between our study and works by other authors could be related to initial fish weight, the diets tested (with zero or low percent SBM), and the thermal conditions under which those studies were conducted. Our results for average weight, specific growth rate, and percent WG in juvenile $T$. macdonaldi might be due to the thermal condition at which fish were acclimated, being $26^{\circ} \mathrm{C}$ similar to their preferred temperature $\left(26.3^{\circ} \mathrm{C}\right.$; Talamás 2001). This temperature could be the optimal condition for totoaba so that their biochemical and metabolic processes are most efficient (Beitinger \& Fitzpatrick 1979), suggesting that fish make better use of the energy obtained from the diet and allocate it to improved performance and growth (Brett 1956, Schram et al. 2013).

Food is a major economic factor in aquaculture, so it is important to use and efficiently provide adequate diets for cultured species (Lekang 2015). FCR is an index that reflects the conversion of food consumed relative to body weight gained (Tacon 1987) and is commonly used to assess economic viability (NRC 2011a). The FCR of T. macdonaldi was influenced only by the experimental diets. The lowest FCR $(0.99 \pm$ 0.02 ) was attained by fish fed the diet with no SBM, and the highest $(1.13 \pm 0.09)$ with the $56 \%$ SBM diet. The FCR range observed in our study was similar to the one reported by Fuentes-Quesada et al. (2018) for this same species $(0.82 \pm 0.03$ to $1.11 \pm 0.07)$ but lower than the one recorded by Madrid et al. (2019) $(1.11 \pm 0.09$ to $1.34 \pm 0.03$ ). In our study, the FCR of fish acclimated at $23^{\circ} \mathrm{C}$ showed a tendency to increase as the proportion of FM replacement increased. The increase in FCR might be because replacing a higher proportion of FM (43 and 56\%) reduces food digestibility due to the high carbohydrates level, particularly non-starch polysaccharides (NSP). Fish fed low-digestibility diets require more food to achieve the same weight gain, resulting in a high FCR (NRC 2011a).

The thermal growth coefficient (TGC) index predicts fish weight relative to water temperature (Alanärä et al. 2001). The T. macdonaldi TGC was not influenced by either acclimation temperature or diet and ranged between $0.93 \pm 0.08\left(\mathrm{D} 2\right.$ at $23^{\circ} \mathrm{C}$ ) and 1.12 $\pm 0.05\left(\mathrm{CD}\right.$ at $\left.23^{\circ} \mathrm{C}\right)$. These indexes are higher than those reported by Perez-Velazquez et al. (2016) (0.018 \pm 0.009 to $0.071 \pm 0.024$ ) when they evaluated the level of lipids in the diet of juveniles of this species acclimated at $28.3^{\circ} \mathrm{C}$. Our values are also higher than those reported by González-Félix et al. (2018) when evaluating diets with prebiotic supplements and commercial probiotics in juveniles $(215.6 \pm 9 \mathrm{~g})$ acclimated at $27.67^{\circ} \mathrm{C}$ (Table 3). TGC values within the range observed in our study were reported by MataSotres et al. (2018) for juvenile T. macdonaldi $(9.5 \pm 0.1 \mathrm{~g})$ when they evaluated the effect of adding DHA to diets based on chicken-waste meal using tallow instead of fish oil to meet the lipid requirements.

TGC values ranged between 0.7 and $1.1( \pm 0.2)$ in juveniles totoaba $(2.7 \pm 0.1 \mathrm{~g})$ acclimated at $26.0^{\circ} \mathrm{C}$ and fed diets containing chicken waste meal as an alternative protein source, as determined by BadilloZapata et al. (2016). These values are closer to those obtained in our study (Table 3), probably because both studies used an alternative protein source that influenced the fish nutritional status, and an acclimation temperature similar to the one preferred by this species.

Fuentes-Quesada et al. (2018) recently documented that the increase of SBM as the protein source in the diet affected the TGC of juvenile $T$. macdonaldi acclimated at $23.3 \pm 1.1^{\circ} \mathrm{C}$ (Table 3 ). They reported TGC values ranging between 1.21 and 1.61, and this index increased as the proportion of SBM decreased (22\%). In our study, neither acclimation temperature nor diet influenced the TGC (0.93 to 1.12) of juvenile T. macdonaldi; the values are low and differ in 0.28 to 0.49 . Other studies have reported that TGC may be negatively affected (Cho \& Bureau 1998) when fish are grown in unfavorable environmental conditions (Kaushik 1998) or fed diets that do not meet their nutritional requirements. In those conditions, fish use a larger amount of energy to perform biological functions such as survival and growth (Willmer et al. 2005, Crawshaw \& Podrabsky 2011).

Also, TGC can increase at low temperatures and decrease at high thermal values (Koskela et al. 1997). In our study, the TGC of totoaba acclimated at $26^{\circ} \mathrm{C}$ was higher and increased in 0.04 and 0.09 units (relative to the control) when SBM was included in diets D1 and D2. Based on the TGC values reported for this species, we suggest that a range between 0.7 and 1.1 is acceptable for this index if the thermal preference interval or the final preferendum $\left(26.3^{\circ} \mathrm{C}\right)$ of juvenile T. macdonaldi is considered since some physiological processes are more efficient under such thermal conditions.

\section{Preferred temperature}

The preferred temperature has been studied in several marine fish species, including Clupea pallasi, Sardinops melanostictus, Oncorhynchus keta, Pagrus major, Oplegnathus fasciatus, Trachurus japonicus, 
Table 3. Biological indices of juvenile Totoaba macdonaldi fed different replacement levels of fish meal with soybean meal (SPC: soy protein concentrate or SBM: soybean meal) or without soy in the diet at different temperatures. SGR: specific growth rate, TGC: thermal growth coefficient.

\begin{tabular}{|c|c|c|c|c|c|c|c|c|}
\hline Author & $\begin{array}{c}\text { Temperature } \\
\left({ }^{\circ} \mathrm{C}\right)\end{array}$ & $\begin{array}{c}\text { Replacement } \\
\text { proportion with } \\
\text { SBM (\%) }\end{array}$ & $\begin{array}{l}\text { Initial weight } \\
(\mathrm{g})\end{array}$ & $\begin{array}{l}\text { Survival } \\
(\%)\end{array}$ & $\begin{array}{l}\text { Final weight } \\
\text { (g) }\end{array}$ & Weeks & SGR $(\%)$ & TGC \\
\hline $\begin{array}{l}\text { Rueda-López } \\
\text { et al. (2011) }\end{array}$ & 25.0 & without soy & $12.1 \pm 0.09$ & $82.2-100$ & $\begin{array}{l}30.0 \pm 1.9 \text { to } \\
84.0 \pm 2.7\end{array}$ & 10 & $\begin{array}{l}1.2 \pm 0.1 \text { to } \\
2.2 \pm 0.0\end{array}$ & -- \\
\hline $\begin{array}{l}\text { Minjarez-Osorio et } \\
\text { al. (2012) }\end{array}$ & 28.4 & without soy & $74.7 \pm 5$ & $93-100$ & $\begin{array}{l}197.0 \pm 2 \text { to } \\
203.6 \pm 2\end{array}$ & 8 & $\begin{array}{l}1.7 \pm 0.2 \text { to } \\
1.8 \pm 0.2\end{array}$ & --- \\
\hline $\begin{array}{l}\text { Bañuelos-Vargas et } \\
\text { al. (2014) }\end{array}$ & 23.0 & $\begin{array}{l}30 \mathrm{SPC} \\
60 \mathrm{SPC}\end{array}$ & 7.5 & 99 & not reported & 6 & --- & --- \\
\hline López et al. (2015) & 23.5 & $\begin{array}{l}30 \mathrm{SPC} \\
60 \mathrm{SPC}\end{array}$ & $7.5 \pm 0.5$ & $97.9-100$ & not reported & 8 & --- & --- \\
\hline $\begin{array}{l}\text { Espinosa-Chaurand } \\
\text { et al. (2015) }\end{array}$ & 20.5 & --- & $26.3 \pm 4.7$ & $88.8-100$ & $\begin{array}{c}30.81 \pm 2.9 \text { to } \\
46.0 \pm 1.7\end{array}$ & 8 & $\begin{array}{l}0.26 \pm 0.14 \text { to } \\
0.99 \pm 0.06\end{array}$ & --- \\
\hline $\begin{array}{l}\text { Badillo-Zapata } \\
\text { et al. (2016) }\end{array}$ & 26.0 & without soy & $2.7 \pm 0.1$ & $52.4-89.3$ & $\begin{array}{l}20.7 \pm 3.4 \text { to } \\
53.2 \pm 1.8\end{array}$ & 12.2 & --- & $0.7-1.1$ \\
\hline $\begin{array}{l}\text { Pérez-Velázquez et } \\
\text { al. (2016) }\end{array}$ & 28.3 & without soy & $128.3 \pm 9.9$ & $95-100$ & $\begin{array}{l}148.25 \pm 16.79 \text { to } \\
227.59 \pm 36.64\end{array}$ & 8 & $\begin{array}{l}0.30 \pm 0.15 \text { to } \\
1.09 \pm 0.35\end{array}$ & $0.018-0.071$ \\
\hline $\begin{array}{l}\text { Trejo-Escamilla et } \\
\text { al. (2016) }\end{array}$ & 23.0 & $\begin{array}{l}15 \text { to } \\
100 \mathrm{SPC}\end{array}$ & $50.0 \pm 1.0$ & $97-100$ & $\begin{array}{l}103.9 \pm 1.8 \text { to } \\
143.9 \pm 28\end{array}$ & 8.5 & --- & --- \\
\hline $\begin{array}{l}\text { Barreto-Curiel } \\
\text { et al. (2018) }\end{array}$ & 26.0 & --- & $3.0 \pm 0.2$ & $94.3-97.1$ & $\begin{array}{l}22.7 \pm 0.3 \text { to } \\
28.1 \pm 0.3\end{array}$ & 8.6 & $\begin{array}{l}3.4 \pm 0.0 \text { to } \\
3.7 \pm 0.0\end{array}$ & --- \\
\hline $\begin{array}{l}\text { Fuentes-Quesada et } \\
\text { al. (2018) }\end{array}$ & 23.3 & $\begin{array}{c}22,44 \text { and } \\
64 \mathrm{SCP}+\mathrm{SBM}\end{array}$ & $71.7 \pm 35.7$ & not reported & not reported & 8 & --- & $1.21-1.61$ \\
\hline $\begin{array}{l}\text { González-Félix } \\
\text { et al. (2018) }\end{array}$ & 27.67 & 21.81 & $215.6 \pm 9.3$ & $97.5-98.3$ & $\begin{array}{l}387.2 \pm 30.9 \text { to } \\
399.1 \pm 38.8\end{array}$ & 15.6 & $\begin{array}{l}0.54 \pm 0.05 \text { to } \\
0.56 \pm 0.9\end{array}$ & $0.04-0.05$ \\
\hline $\begin{array}{l}\text { Mata-Sotres } \\
\text { et al. (2018) }\end{array}$ & 26.0 & without soy & $9.5 \pm 0.1$ & $92.4-100$ & $\begin{array}{l}45.9 \pm 1.4 \text { to } \\
47.9 \pm 2.2\end{array}$ & 9 & $\begin{array}{l}2.58 \pm 0.05 \text { to } \\
2.64 \pm 0.04\end{array}$ & $0.90-0.93$ \\
\hline This study & $23.0-26.0$ & $32,43,56$ & $\begin{array}{l}100.4 \pm 2.0 \text { to } \\
107.7 \pm 2.0\end{array}$ & $97.0-100$ & $\begin{array}{l}223.0 \pm 9.0 \text { to } \\
264.2 \pm 7.9\end{array}$ & 11 & $\begin{array}{l}1.19 \pm 0.10 \text { to } \\
1.53 \pm 0.05\end{array}$ & $0.93-1.12$ \\
\hline
\end{tabular}

and Pseudocaranx dentex (Tsuchida 1995); Gadus morhua (Lafrance et al. 2005), and Paralichthys californicus (Esquer-Méndez et al. 2010), to determine the thermal range chosen by fish or predict the optimum temperature for growth, e.g. Polyprion oxygeneios (Khan et al. 2014) and Solea solea (Schram et al. 2013). Only one study aimed to determine the preferred temperature of T. macdonaldi (Talamás 2001) has been conducted to date. The final preferred temperatures for 2- and 3-month old juveniles were 26.3 and $25.2^{\circ} \mathrm{C}$, respectively. The studies referred to above and the one by Talamás (2001, unpubl. data) examined only the effect of temperature but not the effect of diet quality.

Some studies have evaluated the effect of both temperature and diet. However, these have focused on fish's biological performance, including growth in weight, e.g. in hapuku Polyprion oxygeneios (Tromp et al. 2016) or the body chemical composition and incidence deformities in juvenile tench, Tinca tinca (Kamiński et al. 2017).

Our study evaluated the interaction effect of temperature and diet quality on the preferred temperature and thermal resistance of totoaba. Our results demonstrated that the preferred temperature of juvenile T. macdonaldi was influenced only by acclimation temperature. This response could be attributed to several aspects, including the recent thermal history of the fish (acclimation temperatures), which strongly influences the thermal range selected (Fry 1947), and the thermal history characteristic of the species (Kelsch \& Neill 1990) since juveniles are commonly found between 25 and $29^{\circ} \mathrm{C}$ in surface waters in their natural environment (Flanagan \& Hendrickson 1976).

In this study, juvenile $T$. macdonaldi preferred temperatures higher than their acclimation temperature, which was more evident in fish conditioned at $23^{\circ} \mathrm{C}$. This behavior may suggest a possible adaptive relationship between acclimation temperature and preferred temperature, in which fish chose new thermal values that would maximize various physiological functions, at least at a level higher than the one previously reached at the acclimation temperature (Kelsch \& Neill 1990).

Regarding the diet, it has been reported that replacing up to $60 \%$ of FM with soy protein concentrate (SPC) does not affect the yield of T. macdonaldi (Bañuelos-Vargas et al. 2014, López et al. 2015, Trejo- 
Escamilla et al. 2016). In this study, diets with different percentages of soybean $(32,43$, and $56 \%)$ seemed to meet the nutritional requirements of the biological performance of $T$. macdonaldi and did not affect its preferred temperature. All the fish exposed to the thermal interval during the preferred temperature tests were active along the channel and did not experience thermal stress, which would have caused a higher energy expenditure to avoid adverse conditions.

\section{Critical thermal maximum: CTMax}

Fish physiological condition is key when performing tolerance and thermal resistance tests (Paladino et al. 1980) using either static or dynamic methods (Fry 1947, Beitinger \& Bennett 2000, Beitinger et al. 2000). The CTMax test is used to determine temperature resistance since it evaluates the fish's requirements at the thermal, physiological, and ecological levels (Lutterschmidt \& Hutchison 1997). When CTMax is evaluated in fish, the general tendency is for this indicator to increase with acclimation temperature (Paladino et al. 1980), as observed in species such as Sardinops sagax (Martínez-Porchas \& HernándezRodríguez 2010), Acipenser brevirostrum (Zhang \& Kieffer 2014), and Pseudocrenilabrus multicolor (McDonnell \& Chapman 2015).

Several different behavioral responses were observed in juvenile T. macdonaldi when exposed to increased water temperature to evaluate their resistance. First, they showed increased activity, followed by muscle spasms (MS) and finally losing equilibrium (LE). These responses have been observed in many species, including blenny fish Coryphoblennius galerita, old fish Gobius paganellus, goby Lipophrys pholis, futarra fish Paralipophrys trigloides (Vinagre et al. 2013), and Pseudocrenilabrus multicolor (McDonnell \& Chapman 2015); they are part of organisms' natural behavior to avoid thermal conditions that are adverse for their vital functions (Cowles \& Bogert 1944, Paladino et al. 1980). The MS and LE responses are considered excellent indicators of thermal behavior in fish, as they characterize the endpoint to evaluate CTMax when observed in $100 \%$ of the organisms (Lutterschmidt \& Hutchison 1997).

In this study, when the LE response was observed in $100 \%$ of the fish evaluated, it was considered the endpoint to determine the CTMax of juvenile $T$. macdonaldi; it was influenced by both acclimation temperature and diet. The lowest temperature for LE was observed in fish acclimated at $23^{\circ} \mathrm{C}$ and fed the highest proportion of SBM (56\%: D3). The highest temperature for $\mathrm{LE}$ response was observed in fish acclimated at $26^{\circ} \mathrm{C}$ and fed $\mathrm{CD}(100 \% \mathrm{FM})$.
Unlike our study, other studies on the thermal resistance of fish have not considered the effect of diet quality, mostly when plant-based meals replace the fish meal. Our results with $T$. macdonaldi show the implications that including a high proportion of SBM in the diet might have on CTMax, which is used as an indicator of adaptation and stress in fish (Paladino et al. 1980).

The highest CTMax was recorded in fish acclimated at $26^{\circ} \mathrm{C}$ and fed the control diet (i.e. no SBM). On the other hand, the lowest CTMax was observed in fish acclimated at $23^{\circ} \mathrm{C}$ and fed the diet containing the highest proportion of SBM (56\%: D3). Although this diet (D3) had no significant effect on survival and other biological performance variables, it significantly affected thermal resistance. It is likely that diets containing a high SBM level (43 and 56\%) also had a high content of non-starch polysaccharides (NSP). High NSP levels in fish diets might have adverse effects due to their ability to bind organic and inorganic molecules, which may hinder the use of other nutrients (NRC 2011a). Also, NSPs are a low energy source for fish and affect the digestibility of lipids (NRC 2011a), which could restrict energy production. These considerations possibly influenced the energetic capacity of fish (Jobling 1997); however, complementary studies on other aspects of the energy physiology of totoaba are necessary to understand better the effect of diets where FM has been partially replaced by SBM on the thermal resistance of this species.

Our results showed that, except for thermal resistance, feeding juvenile $T$. macdonaldi with diets containing a high percentage of SBM did not affect their survival, growth in weight, or preferred temperature when acclimated at $26^{\circ} \mathrm{C}$ - similar to their thermal optimum. Further studies on the interaction effect of temperature and the inclusion of vegetable (soybean) meal as a fishmeal replacement in the diet, and its potential effect on CTMax, are needed to use this indicator to predict the response capacity of $T$. macdonaldi under different thermal conditions. Our study laid the basis for considering other biological indicators to determine the feasibility of using SBM in the diet of juvenile T. macdonaldi.

\section{ACKNOWLEDGMENTS}

The Federal Government of Mexico supported this study through the regular funding of CICESE, project number: 623151, and for bonding project with State Commission of Public Services of Tecate (CESPTE, for its acronym in Spanish) number 9269. Thanks especially to Centro Reproductor de Especies Marinas 
del Estado de Sonora (CREMES), at Bahía Kino, Sonora, Mexico, for providing the totoaba eggs, and the Instituto de Investigaciones Oceanológicas de la Universidad Autónoma de Baja California (IIO$\mathrm{UABC}$ ) for allowing the use of recirculation systems and preparation of experimental diets. We are also grateful to Dr. Fernando Barreto Curiel for his support in preparing the diets and Luis Murillo Valenzuela, Jesús Mariscal Medina, and Adrian Celaya Ortega's technical assistance. María Elena Sánchez-Salazar edited the English manuscript.

\section{REFERENCES}

Alanärä, A., Kadri, S., Bierman, S., Teal, L.R., Haenen, O., Van de Vis, H. \& Rijnsdorp, A.D. 2013. Thermal preference of juvenile Dover sole (Solea solea) in relation to thermal acclimation and optimal growth temperature Paspatis, M. (2001). Feeding management. In: Houlihan, D., Boujard, T. \& Jobling, M. (Eds.). Food intake in fish. Blackwell Science, Oxford, pp. 332-347.

Angilletta, M.J. 2009. Thermal adaptation. Oxford University Press, New York.

Association of Official Analytical Chemists (AOAC). 1990. Official methods of analysis. AOAC, Arlington.

Ayodele, A.A. 2010. Replacement of fishmeal with alternative protein sources in aquaculture diets. Master Thesis, University of North Carolina, North Carolina.

Badillo-Zapata, D., Lazo, J.P., Herzka, S.Z. \& Viana, M.T. 2016. The effect of substituting fishmeal with poultry by-product meal in diets for Totoaba macdonaldi juveniles. Aquaculture Research, 47: 1778-1789.

Bañuelos-Vargas, I., López, L.M., Pérez-Jiménez, A. \& Peres, H. 2014. Effect of fishmeal replacement by soy protein concentrate with taurine supplementation on hepatic intermediary metabolism and antioxidant status of totoaba juveniles (Totoaba macdonaldi). Comparative Biochemistry and Physiology Part B: Biochemistry and Molecular Biology, 170: 18-25.

Barreto-Curiel, F., Focken, U., D'Abramo, L.R., Cuarón, J.A. \& Viana, M.T. 2018. Use of isotopic enrichment to assess the relationship among dietary protein levels, growth and nitrogen retention in juvenile Totoaba macdonaldi. Aquaculture, 495: 794-802.

Bennett, W.A. \& Beitinger, T.L. 1997. Temperature tolerance of the sheepshead minnow, Cyprinodon variegatus. Copeia, 1997: 77-87.

Brett, J.R. 1956. Some principles in the thermal requirements of fishes. Quarterly Review Biology, 31: 75-86.

Bicego, K.C., Barros, R.C.H. \& Branco, L.G.S. 2007. Physiology of temperature regulation: comparative aspects. Comparative Biochemistry and Physiology Part A: Molecular and Integrative Physiology, 147: 616-639.

Beitinger, T.L. \& Bennett, W.A. 2000. Quantification of the role of acclimation temperature in temperature tolerance of fishes. Environmental Biology of Fishes, 58: 277-288.

Beitinger, T. \& Fitzpatrick, L. 1979. Physiological and ecological correlates of preferred temperature in fish. American Zoologist, 19: 319-329.

Beitinger, T.L. \& Lutterschmidt, W.I. 2011. Measures of thermal tolerance. In: Farrell, A.P., Stevens, E.D., Cech Jr., J.J. \& Richards, J.G. (Eds.). Encyclopedia of fish physiology: from genome to environment. Academic Press, London, pp. 1695-1702.

Beitinger, T.L., Bennett, W.A. \& McCauley, R.W. 2000. Temperature tolerance of North American freshwater fishes exposed to dynamic changes in temperature. Environmental Biology of Fishes, 58: 237-275.

Brown, P.B., Kaushik, S.J. \& Peres, H. 2008. Protein diet stuffs originating from soybeans. In: Lim, C., Webster, C.D. \& Lee, C. (Eds.). Alternative protein sources in aquaculture diets. Walworth Press, New York, pp. 205-223.

Bückle-Ramírez, L.F., Barón-Sevilla, B., HernándezRodríguez, M., Ledo, A.M., Solís, A.R., Pérez, E.B. \& Hernández, S.A. 2003. Sistema de temperatura, oxígeno y salinidad para la experimentación en ecofisiología. Hidrobiológica, 13: 277-228.

Clark, T.D., Sandblom, E. \& Jutfelt, F. 2013. Aerobic scope measurements of fishes in an era of climate change: respirometry, relevance and recommendations. Journal of Experimental Biology, 216: 27712782.

Cho, C.Y. \& Bureau, D.P. 1998. Development of bioenergetic models and the Fish-PrFEQ software to estimate production, feeding ration and waste output in aquaculture. Aquatic Living Resources, 11: 199210.

Cowles, R.B. \& Bogert, C.M. 1944. A preliminary study of the thermal requirements of desert reptiles. Bulletin of American Museum of Natural History, 83: 18961975.

Crawshaw, L.I. \& Podrabsky, J.E. 2011. Temperature preference: behavioral responses to temperature in fishes. In: Farrell, A.P., Stevens, E.D., Cech Jr., J.J. \& Richards, J.G. (Eds.). Encyclopedia of fish physiology: from genome to environment. Academic Press, London, pp. 758-764.

Eme, J. \& Bennett, W.A. 2009. Critical thermal tolerance polygons of tropical marine fishes from Sulawesi, Indonesia. Journal of Thermal Biology, 34: 220-225. 
Espinosa-Chaurand, L.D., Silva-Loera, A., GarcíaEsquivel, Z. \& López-Acuña, L.M. 2015. Uso de harina de cabeza de camarón como reemplazo proteico de harina de pescado en dietas balanceadas para juveniles de Totoaba macdonaldi (Gilbert, 1890). Latin American Journal of Aquatic Research, 43: 457465.

Esquer-Méndez, J.L., Hernández-Rodríguez, M. \& Bückle-Ramirez, L.F. 2010. Thermal tolerance and compatibility zones as a tool to establish the optimum culture condition of the halibut Paralichthys californicus (Ayres, 1859). Aquaculture Research, 41: 1015-1021.

Eya, J.C., Yossa, R., Perera, D., Okubajo, O. \& Gannam, A. 2017. Combined effects of diets and temperature on mitochondrial function, growth and nutrient efficiency in rainbow trout (Oncorhynchus mykiss). Comparative Biochemistry and Physiology Part B: Biochemistry and Molecular Biology, 212: 1-11.

Findley, L. 2010. Totoaba macdonaldi. The IUCN Red List of Threatened Species 2010: e.T22003A9346099. doi: 10.2305/IUCN.UK.2010-3.RLTS.T22003A9346 099

Flanagan, C.A. \& Hendrickson, R. 1976. Observations on the commercial fishery and reproductive biology of the totoaba Cynoscion macdonaldi in the northern Gulf of California. Fishery Bulletin, 74: 531-544.

Fry, F.E.J. 1947. Effects of the environment on animal activity. University of Toronto Studies: Biological Series 55, Publications of the Ontario Fisheries Research Laboratory, 68: 1-62.

Fuentes-Quesada, J.P., Viana, M.T., Rombenso, A.N., Guerrero-Rentería, Y., Nomura-Solís, M., GómezCalle, V., et al. 2018. Enteritis induction by soybean meal in Totoaba macdonaldi diets: effects on growth performance, digestive capacity, immune response and distal intestine integrity. Aquaculture, 495: 78-89.

Gelbach, F.R., Bryan, C.L. \& Reno, H.A. 1978. Thermal ecological features of Cyprinodon elegans and Gambusia nobilis, endangered Texas fishes. Texas Journal of Science, 30: 99-100.

Guillaume, J., Kaushik, S., Bergot, P. \& Métailler, R. 2004. Nutrición glucídica: interés y límites del aporte de glúcidos. In: Guillaume, J., Kaushik, S., Bergot, P. \& Métailler, R. (Eds.). Nutrición y alimentación de peces y crustáceos. Mundi Prensa, Madrid, pp. 169182.

Glencross, B.D., Booth, M. \& Allan, G.L. 2007. A feed is only as good as its ingredients - a review of ingredient evaluation strategies for aquaculture feeds. Aquaculture Nutrition, 13: 1-34.

Glencross, B.D., Carter, C.G., Duijster, N., Evans, D.E., Dods, K. \& McCafferty, P. 2004. A comparison of the digestive capacity of Atlantic salmon (Salmo salar) and rainbow trout (Oncorhynchus mykiss) when fed a range of plant protein products. Aquaculture, 237: 333-346.

González-Félix, M.L., Gatlin III, D.M., UrquidezBejarano, P., De la Reé-Rodríguez, C., DuarteRodríguez, L., Sánchez, F., et al. 2018. Effects of commercial dietary prebiotic and probiotic supplements on growth, innate immune responses, and intestinal microbiota and histology of Totoaba macdonaldi. Aquaculture, 491: 239-251.

Hardy, R.W. 2008. Farmed fish diet requirements for the next decade and implications for global availability of nutrients. In: Lim, C., Webster, C.D. \& Lee, C.S. (Eds.). Alternate protein sources in aquaculture diets. Haworth Press, New York, pp. 1-16.

Hardy, R.W. \& Tacon, A.G.J. 2002. Fish meal: historical uses, production trends and future outlook for sustainable supplies. In: Srickney, R.R. \& McVey, J.P. (Eds.). Responsible marine aquaculture. CABI, New York, pp. 311-325.

Jobling, M. 1981. Temperature tolerance and the final preferendum- rapid methods for the assessment of optimum growth temperatures. Journal of Fish Biology, 19: 439-455.

Jobling, M. 1997. Temperature and growth: modulation of growth rate via temperature change. In: Wood, C.M. \& McDonald, D.G. (Eds.). Global warming: implications for freshwater and marine fish. Cambridge University Press, Cambridge, pp. 255-253.

Kader, M.A., Bulbul, M., Koshio, S., Ishikawa, M., Yokoyama, S., Nguyen, B.T. \& Komilus, C.F. 2012. Effect of complete replacement of fishmeal by dehulled soybean meal with crude attractants supplementation in diets for red sea bream, Pagrus major. Aquaculture, 350-353: 109-116.

Kamiński, R., Sikorska, J., Polak-Juszczak, L. \& Wolnicki, J. 2017. Effects of temperature on body chemical composition and incidence of deformities in juvenile tench, Tinca tinca (Actinopterygii: Cypriniformes: Cyprinidae), fed a commercial dry diet and/or natural food. Acta Ichthyologica et Piscicatoria, 47: 63-71.

Kaushik, S.J. 1998. Nutritional bioenergetics and estimation of waste production in non-salmonids. Aquatic Living Resources, 11: 211-217.

Khan, J.R., Pether, S., Bruce, M., Walker, S.P. \& Herberta, N.A. 2014. Optimum temperatures for growth and feed conversion in cultured hapuku (Polyprion oxygeneios) - Is there a link to aerobic metabolic scope and final temperature preference? Aquaculture, 430: 107-113.

Kelsch, S.W. \& Neill, W.H. 1990. Temperature preference versus acclimation in fishes: selection for 
changing metabolic optima. Transactions of the American Fisheries Society, 119: 601-610.

Killen, S.S. 2014. Growth trajectory influences temperature preference in fish through an effect on metabolic rate. Journal of Animal Ecology, 83: 1513-1522.

Koskela, J., Pirhonen, J. \& Jobling, M. 1997. Feed intake, growth rate and body composition of juvenile Baltic salmon exposed to different constant temperatures. Aquaculture International, 5: 351-360.

Lafrance, P., Castonguay, M., Chabot, D. \& Audet, C. 2005. Ontogenetic changes in temperature preference of Atlantic cod. Journal of Fish Biology, 66: 553-567.

Lekang, O.I. 2015. Feeding equipment. In: Davis, D.A. (Ed.). Feed and feeding practices in aquaculture. Woodhead Publishing, Cambridge, pp. 349-367.

López, L.M., Durazo, E., Rodríguez-Gómez, A., True, C.D. \& Viana, M.T. 2006. Composición proximal y perfil de ácidos grasos de juveniles silvestres y cultivados de Totoaba macdonaldi. Ciencias Marinas, 32: 303-309.

López, L.M., Flores-Ibarra, M., Bañuelos-Vargas, I., Galaviz, M.A. \& True, C.D. 2015. Effect of fishmeal replacement by soy protein concentrate with taurine supplementation on growth performance, hematological and biochemical status, and liver histology of totoaba juveniles (Totoaba macdonaldi). Fish Physiology and Biochemistry, 41: 921-36.

Lutterschmidt, W.I. \& Hutchison, V.H. 1997. The critical thermal maximum: history and critique. Canadian Journal of Zoology, 75: 1561-1574.

Martínez-Porchas, M. \& Hernández-Rodríguez, M. 2010. Critical thermal maxima and minima of Sardinops sagax caeruleus (Girard 1854) and the analyses of behavioral responses to establish adequate endpoints. Tropical Zoology, 23: 9-20.

Mata-Sotres, J.A., Tinajero-Chavez, A., Barreto-Curiel, F., Pares-Sierra, G., Del Rio-Zaragoza, O.B., Viana, M.T. \& Rombenso, A.N. 2018. DHA (22:6n-3) supplementation is valuable in Totoaba macdonaldi fish oil free feeds containing poultry by-product meal and beef tallow. Aquaculture, 497: 440-451.

McDonnell, L.H. \& Chapman, L.J. 2015. At the edge of the thermal window: effects of elevated temperature on the resting metabolism, hypoxia tolerance and upper critical thermal limit of a widespread African cichlid. Conservation Physiology, 3: 1-13.

Minjarez-Osorio, C., González-Félix, M.L. \& PérezVelázquez, M. 2012. Biological performance of Totoaba macdonaldi in response to dietary protein level. Aquaculture, 362-363: 50-54.

Minjarez-Osorio, C., Castillo-Alvarado, S., Gatlin III, D.M., González-Félix, M.L., Perez-Velazquez, M. \&
Rossi Jr., W. 2016. Plant protein sources in the diets of the sciaenids red drum (Sciaenops ocellatus) and shortfin corvina (Cynoscion parvipinnis): a comparative study. Aquaculture, 453: 122-129.

Morgan, I.J. \& Metcalfe, N.B. 2001. The influence of energetic requirements on the preferred temperature of overwintering juvenile Atlantic salmon (Salmo salar). Canadian Journal of Fisheries and Aquatic Sciences, 58: 762-768.

Naylor, R.L., Hardy, R.W., Bureau, D.P., Chiu, A., Elliott, M., Farrell, A.P., Forster, I., Gatlin, M.D., Goldburg, J.R., Hua, K. \& Nichols, D.P. 2009. Feeding aquaculture in an era of finite resources. Proceedings of the National Academy of Sciences, 106: 15103-15110.

National Research Council (NRC). 2011a. Nutrient requirements of fish and shrimp. National Academies Press, Washington, DC.

National Research Council (NRC). 2011b. Guide for the care and use of laboratory animals. National Academies Press, Washington, DC.

Olsen, R.L. \& Hasan, R.M. 2012. A limited supply of fishmeal: Impact on future increases in global aquaculture production. Trends in Food Science \& Technology, 27: 120-128.

Olvera-Novoa, M.A., Martínez-Palacios, C.A. \& Real de León, E. 1994. Nutrition of fish and crustaceans: a laboratory manual. FAO, Rome.

Paladino, F.V., Spotila, J.R., Schubauer, J.P. \& Kowalski, K.T. 1980. The critical thermal maximum: a technique used to elucidate physiological stress and adaptation in fishes. Review of Canadian Biology, 39: 115-122.

Perez-Velazquez, M., Minjarez-Osorio, C. \& GonzálezFélix, M.L. 2016. Effect of dietary lipid level on growth performance, feed utilization and body composition of totoaba, Totoaba macdonaldi (Gilbert, 1890). Aquaculture Research, 48: 2607-2617.

Pörtner, H.P. 2001. Climate change and temperaturedependent biogeography: oxygen limitation of thermal tolerance in animals. Naturwissenschaften, 88: 137146.

Pulgar, J.M., Aldana, M., Bozinovic, F. \& Ojeda, F.P. 2003. Does food quality influence thermoregulatory behavior in the intertidal fish Girella laevifrons? Journal of Thermal Biology, 28: 539-544.

Reynolds, W.W. \& Casterlin, M.E. 1979. Behavioral thermoregulation and the final preferendum paradigm. American Zoologist, 19: 211-224.

Rueda-López, S., Lazo, J.P., Correa-Reyes, G. \& Viana, M.T. 2011. Effect of dietary protein and energy levels on growth, survival, and body composition of juvenile Totoaba macdonaldi. Aquaculture, 319: 385-390.

Schram, E., Bierman, S., Teal, L.R., Haenen, O., Van de Vis, H. \& Rijnsdorp, A.D. 2013. Thermal preference 
of juvenile Dover sole (Solea solea) in relation to thermal acclimation and optimal growth temperature. Plos One, 8: e61357. doi: 10.1371/journal.pone.00 61357

Tacon, A.G.J., 1987. The nutrition and feeding of farmed fish and shrimp - A training manual. 1. The essential nutrients. FAO Field Document, Project GCP/RLA/ 075/ITA, Field Document 2, Brasilia.

Talamás, R.E. 2001. Efecto de la temperatura sobre la preferencia térmica y el metabolismo de juveniles de Totoaba macdonaldi (Gilbert, 1890) (Pisces: Sciaenidae). Tesis de Magíster, Centro de Investigación Científica y de Educación Superior de Ensenada, Baja California.

Trejo-Escamilla, I., Galaviz, M.A., Flores-Ibarra, M., Álvarez-González, C.A. \& López, L.M. 2016. Replacement of fishmeal by soy protein concentrate in the diets of Totoaba macdonaldi (Gilbert, 1890) juveniles: effect on the growth performance, in vitro digestibility, digestive enzymes and the hematological and biochemistry parameters. Aquaculture Research, 48: $1-20$.

Tromp, J.J., Jones, P.L., Symonds, J.E., Walker, S.P., Pope, A., Pether, S.M.J. \& Afonso, L.O.B. 2016. Effects of commercial diets and temperature on the growth performance and stress response of hapuku (Polyprion oxygeneios). Aquaculture, 452: 128-133.

Received: 14 May 2020; Accepted: 8 November 2020
Tsuchida, S. 1995. The relationship between uppertemperature tolerance and final preferendum of Japanese marine fish. Journal of Thermal Biology, 20: 35-41.

Velazco-Vargas, J., Martínez-Llorens, S., Jover-Cerda, M. \& Tomás-Vidal, A. 2013. Evaluation of soybean meal as protein source for Argyrosomus regius (Asso, 1801) (Sciaenidae). International Journal of Fisheries and Aquaculture, 5: 35-44.

Vinagre, C., Dias, M., Roma, J., Silva, A., Madeira, D. \& Diniz, M.S. 2013. Critical thermal maxima of common rocky intertidal fish and shrimps - a preliminary assessment. Journal of Sea Research, 81: 10-12.

Wang, Y., Ling-Jun, K., Li, C. \& Bureau, D.P. 2006. Effect of replacing fish meal with soybean meal on growth, feed utilization, and carcass composition of cuneate drum (Nibea miichthioides). Aquaculture, 261: 1307-1313.

Watanabe, T. 2002. Strategies for further development of aquatic feeds. Fisheries Science, 68: 242-252.

Willmer, P., Stone, G. \& Johnston, I. 2005. Environmental physiology of animals. Wiley-Blackwell, Oxford.

Zhang, Y. \& Kieffer, J.D. 2014. Critical thermal maximum (CTMax) and hematology of shortnose sturgeons (Acipenser brevirostrum) acclimated to three temperatures. Canadian Journal of Zoology, 92: 215-221. 